\title{
Sea temperature variations mediate annual changes in the diet of Australian fur seals in Bass Strait
}

\author{
Roger Kirkwood $^{1, *}$, Fiona Hume ${ }^{1}$, Mark Hindell ${ }^{2}$ \\ ${ }^{1}$ Research Department, Phillip Island Nature Park, PO Box 97, Cowes, Victoria 3922, Australia \\ ${ }^{2}$ Antarctic Wildlife Research Unit, School of Zoology, University of Tasmania, PO Box 252-05, Hobart, Tasmania 7001, Australia
}

\begin{abstract}
Using a 9-yr data set, we investigated annual fluctuations in the diet of an apex predator, the Australian fur seal Arctocephalus pusillus doriferus. At Seal Rocks (northern Bass Strait), home to $25 \%$ of the entire species population, we assessed diet through collections (1997 to 2006) of scat and regurgitate samples. We identified prey remains of 42 fish taxa and 7 cephalopod taxa. Only crustaceans that were fish parasites or fish prey (amphipods and isopods) were found; no birds were identified in the samples. Six species represented $80 \%$ (as frequency of occurrence) of the fish prey, and the arrow squid Nototodarus gouldi represented $70 \%$ of cephalopod prey. There was significant annual variability in the diet. Principal component analysis indicated this was variability due to the presence of redbait Emmelichthys nitidus in some years, and its near absence and replacement in other years by increased proportions of barracouta Thyrsites atun, red cod Pseudophycis bachus and leatherjackets (Family Triglidae). Generalised Linear Models indicated the annual variation was related to mean sea surface temperatures in western Bass Strait where the seals foraged. Redbait proliferated in cooler years and were less abundant in warmer years. No corresponding annual correlation was evident between the prey assemblages and either annual fisheries catch-per-unit-effort or the annual mean Southern Oscillation Index. The propensity for diet regimes to persist for several years, then change suggests that oceanographic fluctuations probably influence previously unrecognised multi-year cyclic fluctuations of prey and of Bass Strait ecosystems.
\end{abstract}

KEY WORDS: Arctocephalus $\cdot$ Fur seal diet $\cdot$ Sea temperature $\cdot$ Bass strait $\cdot$ Emmelicthys nitidus

Resale or republication not permitted without written consent of the publisher

\section{INTRODUCTION}

Although large-scale climatic features such as the El Niño Southern Oscillation (ENSO) are known to influence the marine environment, the nature of the ecological linkages that lead up the food chain to marine mammals is less well understood. In part, this is due to the lack of long-term data sets that span a sufficient range of climatic variations. The structure of marine ecosystems changes at various temporal scales through seasonal, annual and decadal fluctuations (Hawkins et al. 2003, Evans et al. 2005), and in response to catastrophic events that may alter food chains (Trillmich \& Ono 1991, Ward et al. 2001). A means of detecting subtle ecosystem changes is through monitoring foraging parameters of apex predators, such as pinnipeds (Hindell et al. 2003). Pinniped diet, for example, varies temporally in relation to differences in prey distribution and abundance (Lea et al. 2002, Reid et al. 2006). In South America, oceanographic variations related to ENSO events can cause dramatic changes in local fish assemblages, influencing the diet and breeding success of pinnipeds (Trillmich \& Ono 1991). Monitoring of pinniped diet in conjunction with oceanographic variables can provide insights into causes and effects of fluctuations in marine communities.

Between 1998 and 2006, we monitored the diet of an apex marine predator in southeastern Australia shelf waters (the Australian fur seal Arctocephalus pusillus doriferus) at Seal Rocks in northern Bass Strait. Australian fur seals breed mainly in Bass Strait, between Tasmania and the Australian mainland, and forage throughout southeastern Australian shelf waters (Warneke \& Shaughnessy 1985, Kirkwood et al. 2005, 2006, 
Arnould \& Kirkwood 2008). Like other fur seals, such as the New Zealand fur seal A. forsteri (Harcourt et al. 2002), Australian fur seals are generalist predators and consume a range of benthic and pelagic prey; they exhibit some spatial and temporal variations in diet. During the 1920s and 1940s, their diet at breeding colonies in northern Bass Strait was determined by inspection of stomach contents in several shot animals, and comprised mainly barracouta (also known as snoek Thyrsites atun), cephalopods, and southern rock lobster Jasus novaehollandiae (Lewis 1930, McNally \& Lynch 1954). In the 1980s and 1990s, the diet, determined from prey hard parts in scats and regurgitates at sites in southern Bass Strait and south of Tasmania, comprised mainly redbait Emmelichthys nitidus, jack mackerel Trachurus declivis, leatherjackets (Family Monocanthidae) and arrow squid Nototodarus gouldi (Gales et al. 1993, Gales \& Pemberton 1994, Hume et al. 2004). Between 1997 and 2001 in northeastern Bass Strait, the same prey, plus red cod Pseudophycis bachus were the key species (Littnan 2003, Littnan et al. 2007); during 2001/2002 in South Australian waters, redbait was the dominant prey of adult male Australian fur seals (Page et al. 2005). Although variation is evident in the diets, factors influencing the variation are unclear, partly because sampling has been opportunistic and/or short term.

Bass Strait is a shallow ( $<100 \mathrm{~m}$ maximum depth) marine basin at $39^{\circ} \mathrm{S}$ on the continental shelf between mainland Australia and Tasmania. It is well mixed vertically, but characterized by a limited nutrient regime (Gibbs et al. 1986). The central basin is quite stagnant, with weak currents and long flushing times (>160 d, Sandery \& Kämpf 2004). Subtle changes in surrounding water bodies may influence the flow rates and water quality within Bass Strait (Evans \& Middleton 1998). Water bodies that may enter the strait are the Subantarctic Surface Water (SASW) from the south, South Australian Current (SAC) from the northwest and East Australian Current (EAC) from the northeast (Newell 1961). Most current flow is eastward and enhanced by the predominantly westerly winds across southern Australia (Blackman et al. 1987, Middleton \& Bye 2007).

Inter-annual variability in Bass Strait water temperature and productivity may be influenced by broad-scale events, including the ENSO in the western Pacific Ocean (Kidson \& Renwick 2002, Middleton \& Bye 2007, Middleton et al. 2007). ENSO cycles influence the relative strength of the Leeuwin Current, causing variability in ocean productivity and species' movements (Pearce \& Phillips 1988, Wilson et al. 2001). The Leeuwin Current moves southwards along the coast of Western Australia and feeds into the SAC (Kidson \& Renwick 2002). Sea temperature anomalies in Bass Strait may also be influenced by the Antarctic Circumpolar Wave (ACW) (which pulses colder then warmer waters northwards from the Southern Ocean in a 4 to 5 yr cycle, White \& Peterson 1996), or by meteorological influences (Blackman et al. 1987).

In this study we aimed to (1) quantify the interannual changes in Australian fur seal diet at the Seal Rocks colony in northern Bass Strait through a 9 yr program of scat sampling, (2) relate the variations in prey assemblages to broad scale oceanographic variables, and (3) assess the ecological implications of these relationships for variability in southeastern Australian marine ecosystems.

\section{MATERIALS AND METHODS}

Study area and sample collection. This study was based in northern Bass Strait at Seal Rocks, a colony of 20000 to 25000 Australian fur seals (about $25 \%$ of the species' population, Kirkwood et al. 2005). Scats deposited on Seal Rocks derive from prey eaten within $200 \mathrm{~km}$, assuming Australian fur seals can travel about $100 \mathrm{~km} \mathrm{~d}^{-1}$ (Kirkwood et al. 2006, Arnould \& Kirkwood 2008), and the mean passage rate of prey through the digestive system of fur seals is about $2 \mathrm{~d}$ (derived from captive Antarctic fur seals Arctocephalus gazella, Staniland 2002). Seals tracked from Seal Rocks tended to forage within western Bass Strait (Kirkwood et al. 2006, Arnould \& Kirkwood 2008).

Fresh scat and regurgitate samples were collected between 1998 and 2006 at Seal Rocks $\left(38^{\circ} 30^{\prime} \mathrm{S}\right.$, $145^{\circ} 10^{\prime} \mathrm{E}$; Fig. 1, Table 1). We aimed to make monthly sample collections, but this was not always possible for logistical reasons. Like other otariids, Australian fur seals routinely regurgitate stomach contents that are difficult to digest and too large to pass from the stomach into the intestine. Actual diets of the seals may be assessed from a combination of the scats and regurgitates, but the ratio of one to the other is difficult to determine due to differences in passage and production rates (Gales et al. 1993). Also, at Seal Rocks, gulls (Larus dominicanus and L. novaehollandiae) readily consume seal regurgitates, which reduces the number available for collection (R. Kirkwood pers. obs.). Accordingly, we focus on interannual variation in scat data, although regurgitate data are presented for comparison.

Samples were placed in separate plastic bags and stored frozen until analysis. In the laboratory, samples were soaked in warm water, then washed through a series of sieves (from 1 to $0.2 \mathrm{~mm}$ ). Diagnostic remains of fish (otoliths, mouthparts, body plates, spines, etc.), cephalopods (beaks) and crustaceans (exoskeletons and carapace fragments) were collected. 


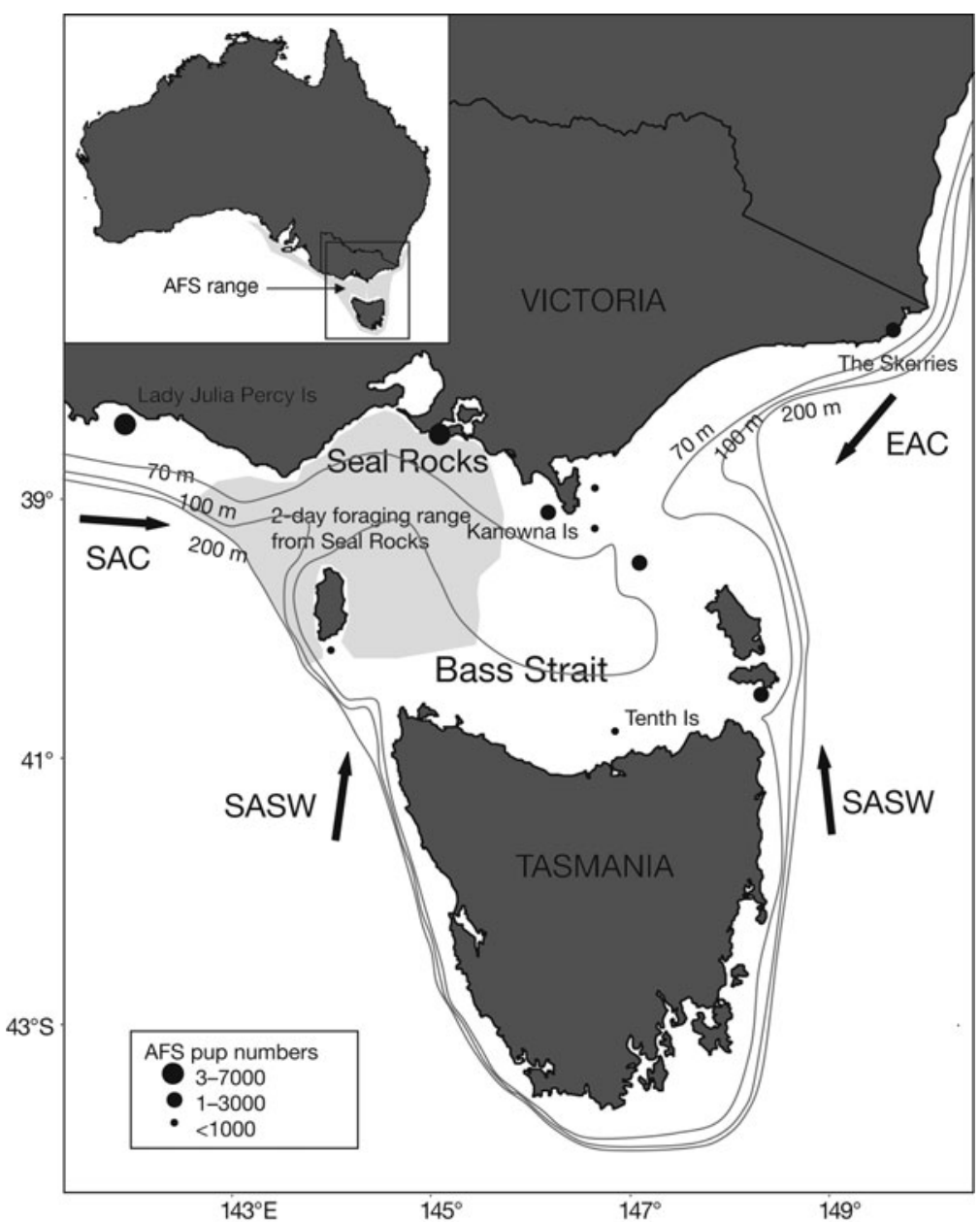

Fig. 1. Arctocephalus pusillus doriferus. Location of Seal Rocks and other colonies of Australian fur seals (AFS) and water currents that may enter Bass Strait (SAC: South Australia Current; EAC: East Australia Current; SASW: Subantarctic Surface Water). The estimated $2 \mathrm{~d}$ foraging range of seals from Seal Rocks is indicated by light grey shading. Bottom depth contours are shown
Saggital otoliths were identified by comparison with reference collections and an atlas (Furlani et al. 2007). Fish prey were identified mostly to species and genus, although identification was possible only to family for Monocanthidae (leatherjackets), Triglidae (gurnard), Macrouridae (whiptail), Ostracontidae (cowfish), Myctophidae (Myctophid) and Bothidae (flounder). Also, scorpion fish other than common gurnard perch Neosebastes scorpaenoides and reef ocean perch Helicolenus percoides were assigned to the Order Scorpaeniformes. Pseudophycis spp. (red cod $P$. bacchus and bearded rock cod $P$. barbata) could not be distinguished using a microscope, but were separable by microchemical analysis. Laser ablation techniques showed that the core region of bearded rock cod otoliths have significantly higher lithium enrichment than red cod otoliths (J. Kemp unpubl. data). Only red cod otoliths were identified in the diet samples. All identifiable Gempylidae otoliths were from abundant barracouta Thyrsites atun, so eroded Gempylid otoliths were assumed to be of this species rather than the less common gemfish Rexea solandri. Likewise, eroded Trachurus spp. otoliths were assumed to be from the abundant jack mackerel T. declivis, although some may have been from yellowtail T. novaezelandiae. Very eroded otoliths of Trachurus spp. and redbait Emmelichthys nitidus are similar, and where species could not be positively identified, they were assigned to species based on proportional occurrence of the identified otoliths of these species in the collection

Table 1. Arctocephalus pusillus doriferus. Seal diet samples collected at Seal Rocks. Within table cells (month $\times$ year), the 1 st value gives numbers of scats, the 2nd value in italics gives numbers of scats with identifiable fish remains that were incorporated in frequency of occurrence estimates, and the 3rd value in parentheses gives number of regurgitates

\begin{tabular}{|c|c|c|c|c|c|c|c|c|c|}
\hline Month & 1998 & 1999 & 2000 & 2001 & 2002 & 2003 & 2004 & 2005 & 2006 \\
\hline $\mathrm{J}$ & $1614(2)$ & & & & & & & $2823(2)$ & $119(0)$ \\
\hline $\mathrm{F}$ & $2817(3)$ & $2218(0)$ & & & $1916(6)$ & & & & \\
\hline M & $2012(0)$ & & & & & & $2322(0)$ & & 2520 (1) \\
\hline A & & $256(3)$ & $2317(0)$ & & $1911(1)$ & $2117(0)$ & & $2724(2)$ & $3125(0)$ \\
\hline M & $2417(2)$ & $1610(0)$ & & 117 (1) & $2317(2)$ & & $2723(0)$ & & $2922(0)$ \\
\hline $\mathrm{J}$ & 2421 (3) & $2624(0)$ & & & $2522(0)$ & & & $2823(0)$ & \\
\hline $\mathrm{J}$ & $2826(0)$ & $2423(2)$ & $3124(0)$ & & & $2119(0)$ & $2819(1)$ & $2922(0)$ & $2421(0)$ \\
\hline A & $1410(2)$ & & & $2518(1)$ & $2521(0)$ & $3226(0)$ & $2424(0)$ & $3127(0)$ & \\
\hline $\mathrm{S}$ & & & $2815(0)$ & $2517(1)$ & $2422(0)$ & & $2320(1)$ & $3428(0)$ & $2421(0)$ \\
\hline $\mathrm{O}$ & $1713(1)$ & $2823(1)$ & & & & $2510(0)$ & $2925(0)$ & $2822(0)$ & $3225(0)$ \\
\hline $\mathrm{N}$ & & $1212(0)$ & & & & & & & \\
\hline $\mathrm{D}$ & & $1711(0)$ & & & & & & & \\
\hline Total & $171130(13)$ & $170127(6)$ & $8256(0)$ & $6142(3)$ & $135109(9)$ & $9972(0)$ & $154133(2)$ & $205169(4)$ & $176143(1)$ \\
\hline Months & 8 & 8 & 3 & 3 & 6 & 4 & 6 & 7 & 7 \\
\hline
\end{tabular}


from that month. Similarly, lapillus and astericus otoliths of redbait, jack mackerel or barracouta (which could not be attributed to species) were occasionally present without saggital otoliths. In these cases, they were assumed to be in ratios at which identifiable otoliths occured for these species in the month's sample. Otoliths that could not be identified to taxonomic group, usually due to severe erosion, were recorded as unidentified.

Counts of paired left and right otoliths provided estimates of the minimum numbers of fish present in each sample. In addition to otoliths, the mouthparts, spines and distinctive vertebral growths of leatherjacket species, and mouthparts of wrasse species and barracouta indicated the presence of these fish taxa. The presence of cowfish (Family Ostracontidae) was indicated by characteristic hexagonal body plates.

Cephalopod beaks were identified by comparing lower beaks with reference collections and an atlas ( $\mathrm{Lu}$ \& Ickeringill 2002). The number of lower cephalopod beaks identified was recorded to provide a minimum number of cephalopods in a sample. As recognised previously (Hume et al. 2004), Octopus berrima and O. pallidus could not be distinguished, and so were recorded as O. berrima/O. pallidus.

Analyses. Separate scat and regurgitate profiles and separate fish and cephalopod profiles were prepared and compared for overall diet characterisation (Gales et al. 1993, Gales \& Pemberton 1994, Fea et al. 1999). The prevalence of each prey group was quantified firstly using percentage numerical abundance (NA) across all samples, then proportional frequency of occurrence (PFO) based on the proportion of samples that contained identified prey remains of each taxon. A second frequency of occurrence (mean PFO) was determined by averaging $\mathrm{PFO}$ across the months sampled within each year, then averaging across years. This ensured that, despite sample size variation between months and sampling frequency variation between years, each month sampled contributed equally to annual diet estimates and each year contributed equally to the overall estimate. Finally, contributions by mass were determined. Otoliths and beaks were scored according to their level of erosion and those scored as pristine or near pristine were measured digitally under a binocular microscope. Prey lengths and masses were derived from otolith and beak (lower rostral) lengths using published equations (Gales \& Pemberton 1990, Lu \& Ickeringill 2002). Based on the mean masses and both NA and PFO of prey, we estimated prey contributions by mass to the diet. There are numerous biases associated with predicting marine mammal diet based on the recovery of partially digested prey hard-parts (Tollit et al. 1997, Staniland 2002). Accordingly, although our estimates signal im- portant prey species and age classes, they only approximate the actual diet and some important prey may be under-represented.

Multivariate data analyses. Multivariate analysis focused on scat data only, as these comprised by far the largest data set (981 samples with identifiable prey spread across all sampling dates, Table 1). As the scats contained 41 species from 52 sampling occasions (Tables 1 \& 2), we used a multivariate approach to minimise the number of dimensions for subsequent analyses. Only species that occurred in at least 3 scats in 3 monthly samples were included to eliminate the influence of rare species, and this reduced the number of species to 13 (Table 2). We used the PFO data for all of these analyses. A principal component analysis (PCA) was performed on the complete data set (i.e. all $51 \mathrm{PFO}$ values for the 13 species), and the resulting principal components (PCs) with the greatest explanatory power were used as variables in further analyses. The relative importance of each species in each PC was assessed by examination of the individual loadings in that principal component. Each PC was therefore a single variable that contained information on the relative importance of each prey species for each of the 52 samples. These vectors are orthogonal to each other, ensuring they can be treated as independent variables.

Generalised linear models. Following PCA, we then used a series of Generalised Linear Models (GLMs) to examine the importance of several covariates in the dietary data summarised in the PCs. Our covariates were 'month', 'year' and the mean annual Southern Oscillation Index (SOI). We used the Troup SOI, which is the standardised anomaly of the mean sea level pressure difference between Tahiti and Darwin (available from Bureau of Meteorology, Australia: www.bom.gov.au/climate/). Other factors included were the mean annual sea surface temperature (MSST) for western Bass Strait, interpolated from monthly mean SST data for western Bass Strait $\left(39^{\circ} \mathrm{S}\right.$, $144^{\circ} \mathrm{E}$ to $40^{\circ} \mathrm{S}, 145^{\circ} \mathrm{E}$ ) obtained from the National Centre for Atmospheric Research (NCAR) Comprehensive Oceanic-Atmospheric Data Set (COADS available at: nomads.ncdc.noaa.gov/), and the mean annual catch per unit effort (CPUE) data for the area within $200 \mathrm{~km}$ of Seal Rocks, the presumed range across which seals forage and return to deposit scat at Seal Rocks, obtained from the database of the Australian Fisheries Management Authority (AFMA), Canberra.

Model selection was based on Akaike's information criterion corrected for small samples $\left(\mathrm{AIC}_{\mathrm{C}}\right.$, Burnham \& Anderson 2002). The information-theoretic weight of evidence $\left(W+_{i}\right)$ for each predictor (month, year, etc.) was calculated by summing the model $\mathrm{AIC}_{\mathrm{C}}$ weights 
Table 2. Arctocephalus pusillus doriferus. Percentage numerical abundance (NA), overall proportional frequency of occurrence (PFO) and mean monthly frequency of occurrence (xPFO, see 'Materials and methods-Analyses' for description) of prey in seal scat samples collected at Seal Rocks between 1998 and 2006

\begin{tabular}{|c|c|c|c|c|}
\hline \multicolumn{2}{|l|}{ Taxon } & \multirow{2}{*}{$\begin{array}{l}\text { NA } \\
(\%)\end{array}$} & \multirow{2}{*}{$\begin{array}{l}\mathrm{PFO} \\
(\%)\end{array}$} & \multirow{2}{*}{$\begin{array}{c}\mathrm{xPFO} \\
(\%)\end{array}$} \\
\hline \multicolumn{2}{|l|}{ Fishes } & & & \\
\hline Redbait $^{\mathrm{a}}$ & Emmelichthys nitidus & 52.9 & 16.9 & 19.9 \\
\hline Leatherjacket $^{\mathrm{a}}$ & Family Monocanthidae & 6.4 & 14.7 & 17.7 \\
\hline Jack mackerel $^{\mathrm{a}}$ & Trachurus declivis & 11.4 & 9.4 & 12.8 \\
\hline Barracouta $^{a}$ & Thyrsites atun & 4.2 & 9.1 & 11.5 \\
\hline Red $\operatorname{cod}^{\mathrm{a}}$ & Pseudophycis bachus & 8.0 & 8.3 & 9.5 \\
\hline Gurnard $^{\mathrm{a}}$ & Family Triglidae & 5.4 & 6.7 & 6.9 \\
\hline Silverbelly ${ }^{\mathrm{a}}$ & Parequula melbournesis & 0.9 & 1.8 & 2.2 \\
\hline Unknown sp1 $1^{\mathrm{a}}$ & & 1.3 & 1.9 & 2.1 \\
\hline Silver trevally ${ }^{\mathrm{a}}$ & Pseudocaranx dentex & 0.9 & 1.3 & 1.8 \\
\hline Silver dory & Cyttus australis & 0.5 & 1.1 & 1.7 \\
\hline Tiger flathead & Neoplatycephalus richardsoni & 0.6 & 1.1 & 1.7 \\
\hline Western red mullet $^{\mathrm{a}}$ & Upeneichthys vlamingii & 0.7 & 1.4 & 1.4 \\
\hline Sand flathead & Platycephalus bassensis & 0.9 & 1.1 & 1.4 \\
\hline Silverside $^{\mathrm{a}}$ & Argentina australiae & 0.7 & 1.2 & 1.1 \\
\hline Anchovy & Engraulis australis & 1.3 & 0.8 & 1.1 \\
\hline Pink ling & Genypterus blacodes & 0.5 & 1.0 & 1.0 \\
\hline Reef ocean perch & Helicolenus percoides & 0.4 & 0.7 & 0.9 \\
\hline Apogonidae & Family Apogonidae & 1.1 & 0.6 & 0.7 \\
\hline Wrasse & Family Labridae & 0.1 & 0.3 & 0.5 \\
\hline Blue warehou & Seriolella brama & 0.1 & 0.2 & 0.4 \\
\hline Ocean perch & Helicolenus sp. & 0.2 & 0.3 & 0.4 \\
\hline Stargazer & Family Uranoscopidae & 0.1 & 0.2 & 0.4 \\
\hline Spotted warehou & Seriolella punctata & 0.1 & 0.1 & 0.4 \\
\hline Scorpionfish & Order Scorpaeniformes & 0.1 & 0.2 & 0.3 \\
\hline Redfish & Centroberyx affinis & 0.1 & 0.2 & 0.3 \\
\hline Warehou & Serioella spp. & 0.1 & 0.2 & 0.3 \\
\hline Flounder & Family Bothidae & 0.2 & 0.3 & 0.3 \\
\hline Pilchard & Sardinops neopilchardus & 0.2 & 0.2 & 0.2 \\
\hline Morwong & Nemadactylus spp. & $<0.1$ & 0.1 & 0.2 \\
\hline White cardinalfish & Epigonis denticularis & 0.1 & 0.2 & 0.2 \\
\hline Yellow eyed mullet & Aldrichetta forsteri & 0.3 & 0.1 & 0.1 \\
\hline Eastern school whiting & Sillago flindersii & 0.1 & 0.2 & 0.1 \\
\hline Snapper & Pagrus auratus & 0.1 & 0.0 & 0.1 \\
\hline Common gurnard perch & Neosebastes scorpaenoides & $<0.1$ & 0.0 & 0.1 \\
\hline Bastard trumpeter & Latridopsis forsteri & $<0.1$ & 0.0 & 0.1 \\
\hline Hardyhead & Atherinidae spp. & $<0.1$ & 0.0 & 0.1 \\
\hline Whiptail & Family Macouridae & $<0.1$ & 0.0 & 0.1 \\
\hline Marblefish & Dactylosargus arctidens & $<0.1$ & 0.0 & $<0.1$ \\
\hline Hapuku & Polyprion oxygeneios & $<0.1$ & 0.0 & $<0.1$ \\
\hline Slimy (blue) mackerel & Scomber australasicus & $<0.1$ & $<0.1$ & $<0.1$ \\
\hline Cowfish & Family Ostracionthidae & $<0.1$ & $<0.1$ & $<0.1$ \\
\hline \multicolumn{5}{|c|}{$\begin{array}{l}\text { Total }(\mathrm{n}) \text { : Unidentified/eroded otoliths }=318 \text {; identified fish }=5139 ; \text { samples } \\
\text { with identifiable fish remains }=981\end{array}$} \\
\hline \multicolumn{5}{|l|}{ Cephalopods } \\
\hline Arrow squid ${ }^{\mathrm{a}}$ & Nototodarus gouldi & 74.1 & 73.0 & \\
\hline Calamari squid & Sepioteuthis australis & 10.5 & 11.1 & \\
\hline Pale/keeled octopus & Octopus pallidus/O. berrima & 6.0 & 8.7 & \\
\hline Maori octopus & Octopus maorum & 1.9 & 4.0 & \\
\hline Southern argonaut & Argonauta nodosa & 4.9 & 1.6 & \\
\hline Giant cuttlefish & Sepia apama & 2.3 & 1.6 & \\
\hline New Holland cuttlefish & Sepia novaehollandiae & 0.4 & 0.8 & \\
\hline \multicolumn{5}{|c|}{$\begin{array}{l}\text { Total }(\mathrm{n}) \text { : Unidentified/eroded cephalopods }=183 ; \text { identified } \\
\text { cephalopods }=266 ; \text { samples with identifiable cephalopods }=118\end{array}$} \\
\hline Crustaceans & \multicolumn{4}{|l|}{ Samples with crustaceans $=59$} \\
\hline $\begin{array}{l}{ }^{\text {a }} \text { Species included in the } n \\
\mathrm{mo}^{-1} \text { in at least } 3 \text { monthl }\end{array}$ & $\begin{array}{l}\text { multivariate analyses (i.e. occ } \\
\text { y samples) }\end{array}$ & red & t le & $\mathrm{sca}$ \\
\hline
\end{tabular}

$\left(w_{i}\right)$ over all models in which each term appeared. However, the $W+_{i}$ values are relative, not absolute, because they will be $>0$ even if the predictor has no contextual explanatory importance (Burnham \& Anderson 2002). To judge which predictors were most relevant, a baseline for comparing relative $\mathrm{WH}_{i}$ across predictors was required, so we randomized the data for each predictor separately, re-calculated $W+_{i}$, and repeated this procedure 100 times for each predictor. The median of this new randomized $\mathrm{W}_{i}$ distribution for each predictor was taken as the baseline (null) value $\left(w+t_{0}\right)$. For each term, the absolute weight of evidence $(\Delta w+)$ was obtained by subtracting $W+_{0}$ from $W+_{i}$, and predictors with $\Delta w+$ of $\leq 0$ have essentially no explanatory power (Burnham \& Anderson 2002). Specific model comparisons were based on the information-theoretic evidence ratio (ER) which is equivalent to the $\mathrm{AIC}_{\mathrm{C}}$ weight $(w)$ of the full model divided by the $w$ of the null model (Burnham \& Anderson 2002). Higher ER values indicate higher likelihoods of the tested model relative to the null. We also calculated the percent deviance explained (\%DE) by each model constructed as a measure of model goodness-of-fit. All statistical analyses were done using the $\mathrm{R}$ Package (Ver. 2.4.1; R Development Core Team 2004, available at: www. r-project.org/).

\section{RESULTS}

\section{Overall diet}

Across the 52 sample dates, we collected 1253 scats and 38 regurgitates from which we identified diagnostic remains of a minimum of 5211 fish from 42 different taxa and 389 cephalopods from 7 taxa (Tables $2 \& 3$ ). No samples contained bird remains. Crustaceans, exclusively amphipod and isopod exoskeletons, were recognised in 55 scats and 2 regurgitates, and were probably derived from either external parasites or stomach contents of the prey. 
Based on scat samples, the most numerically important fish species (contributing $>5 \%$ ) were redbait $(58 \%)$, red cod $(8.5 \%)$, jack mackerel (8.0\%) and leatherjackets $(6.3 \%)$. Using frequency of occurrence, the same species, plus barracouta and gurnard were recognised as principal prey. Numerically important cephalopods were arrow squid $(74.0 \%$ of cephalopods), calamari squid (10.4\%) and pale/keeled octopus $(6.4 \%)$. Based on regurgitates, the most important fish species were red cod $(54.2 \%)$, leatherjackets $(9.7 \%)$, wrasse $(9.7 \%)$ gurnard $(6.9 \%)$ and eastern school whiting $(5.6 \%)$, while important cephalopods were arrow squid (82.1\%) and calamari squid (9.8\%).

Sufficient pristine otoliths (most from scats) and beaks (most from regurgitates) were recovered to estimate the sizes of key prey. Modal fork lengths for fish and mantle lengths for cephalopods indicated that most prey were between 100 and $300 \mathrm{~mm}$ body length (Table 4). The seals preyed on mature fish of most species; however, juveniles accounted for $95 \%$ of red cod, $90 \%$ of redbait and jack mackerel, and $50 \%$ of barracouta.

There was a significant change in the sizes of arrow squid (Fig. 2). Up to April 2002, lower-rostral lengths $( \pm \mathrm{SD})$ of arrow squid beaks averaged $7.3 \pm 1.5 \mathrm{~mm}(\mathrm{n}=$ 92, mantle length $288 \pm 51 \mathrm{~mm}$, mass $707 \pm 286 \mathrm{~g}$ ) and from April 2002 to October 2005 they averaged 3.6 \pm 1.4 $\mathrm{mm}$ ( $\mathrm{n}=71$, mantle length $166 \pm 49 \mathrm{~mm}$, mass $\left.130 \pm 156 g_{;} z=15.65, \mathrm{p}<0.01\right)$.

Reconstructing the diet based on prey mass altered the apparent order of importance of the main prey (Table 5). The reconstruction emphasised the value of larger bodied prey, such as barracouta, arrow squid and tiger flathead, and reduced that of smaller prey, such as leatherjackets and anchovy.

\section{Multivariate analysis}

The first three PCs accounted for $77.8 \%$ of the total variance (Table 6 ). Principal Component 1 (PC1) explained $46.4 \%$, PC2 $18.8 \%$ and PC3 12.6\%. All remaining PCs explained less than $10 \%$ of the total variance and were not used in subsequent analyses. PC1 was dominated by the presence of redbait (Table 6). Leatherjacket, barracouta and bearded/red cod were at the other end of the vector. The other species were unimportant (Fig. 3). PC2 was dominated by jack mackerel, bearded/ red cod and gurnard. PC3 had leather- jacket, gurnard, redbait and jack mackerel as its primary species.

\section{Diet by month and year}

The most parsimonious GLM testing for the effect of month and year on PC1 included only year (Table 7). This model provided the best fit and explained 31.0\% of the deviance. The very large evidence ratio $(\mathrm{ER}=$ $19124)$ indicates very strong support for this model, and, hence, that PC1 varied among years. The yearmonth model had a similar $\mathrm{AIC}_{\mathrm{C}}$ value, but explained only an additional $0.3 \%$ of the deviance, indicating that month had negligible influence.

The GLM testing for the effect of month and year on PC2 indicated the month+year model was the most parsimonious. However, this model explained only $5.3 \%$ more of the deviance than the month only model (which itself explained $23.8 \%$ ), suggesting that PC2 was strongly influenced by month. There was strong support for this model $(E R=2320)$.

PC3 varied mainly by year, and month had little influence (Table 7). As our study is primarily concerned with inter-annual variation in diet, we have chosen to focus the remainder of the analysis on PC1, the most important of the components, and the one that varied among years.

Table 3. Arctocephalus pusillus doriferus. Percentage numerical abundance (NA) and overall proportional frequency of occurrence (PFO) of prey in seal regurgitate samples collected at Seal Rocks between 1998 and 2006

\begin{tabular}{|c|c|c|c|}
\hline & & NA ( $\%)$ & PFO (\%) \\
\hline \multicolumn{4}{|l|}{ Fishes } \\
\hline Red cod & Pseudophycis bachus & 54.2 & 26.7 \\
\hline Leatherjacket & Family Monocanthidae & 9.7 & 23.3 \\
\hline Wrasse & Family Labridae & 9.7 & 20.0 \\
\hline Gurnard & Family Triglidae & 6.9 & 3.3 \\
\hline Eastern school whiting & Sillago flindersii & 5.6 & 3.3 \\
\hline Alfonsin & Beryx splendens & 4.2 & 3.3 \\
\hline Pink ling & Genypterus blacodes & 2.8 & 3.3 \\
\hline Redbait & Emmelichthyis nitidus & 1.4 & 3.3 \\
\hline Scorpionfish & Order Scorpaeniformes & 1.4 & 3.3 \\
\hline Barracouta & Thyristes atun & 1.4 & 3.3 \\
\hline Marblefish & Dactylosargus arctidens & 1.4 & 3.3 \\
\hline Tiger flathead & Neoplatycephalus richardsoni & 1.4 & 3.3 \\
\hline \multicolumn{4}{|c|}{$\begin{array}{l}\text { Total }(\mathrm{n}) \text { : Unidentified/eroded otoliths }=8 \text {; identified fish }=72 ; \text { samples with } \\
\text { identifiable fish remains }=21\end{array}$} \\
\hline \multicolumn{4}{|l|}{ Cephalopods } \\
\hline Arrow squid & Nototodarus gouldi & 82.1 & 52.0 \\
\hline Pale/Keeled octopus & Octopus pallidus/O. berrima & 4.9 & 20.0 \\
\hline Calamari squid & Sepioteuthis australis & 9.8 & 16.0 \\
\hline Giant cuttlefish & Sepia apama & 2.4 & 8.0 \\
\hline Maori octopus & Octopus maorum & 0.8 & 4.0 \\
\hline
\end{tabular}


Table 4. Arctocephalus pusillus doriferus. Modal fork lengths of fish and mantle lengths of cephalopods that were prey of seals, based on sizes of pristine otoliths and beaks found in diet samples, plus lengths and ages at maturity, and \% of prey that were mature (maturity data from Kailola et al. 1993, Marshall et al. 1993, Horn 2002, Jackson et al. 2003, Welsford \& Lyle 2003). For taxonomic species names see Tables $2 \& 3$

\begin{tabular}{|lcccccc|}
\hline Prey & $\mathrm{n}$ & $\begin{array}{c}\text { Modal } \\
\text { length } \\
(\mathrm{mm})\end{array}$ & $\begin{array}{c}\text { Range } \\
(\mathrm{mm})\end{array}$ & $\begin{array}{c}\text { Length at } \\
\text { maturity } \\
(\mathrm{mm})\end{array}$ & $\begin{array}{c}\text { Age at } \\
\text { maturity } \\
(\mathrm{yr})\end{array}$ & $\begin{array}{c}\text { Mature } \\
\text { prey } \\
(\%)\end{array}$ \\
\hline Pale octopus & 18 & 54 & $17-90$ & 50 & $?$ & - \\
Anchovy & 69 & 86 & $65-110$ & 60 & 1 & 100 \\
Leatherjacket & 26 & 110 & $50-260$ & $?$ & - & - \\
Redbait & 1242 & 140 & $80-260$ & 245 & 2 & 10 \\
Red cod & 202 & 170 & $30-470$ & 320 & 1 & 5 \\
Jack mackerel & 395 & 110,190 & $65-370$ & 300 & $3-4$ & 10 \\
Calamari squid & 26 & 206 & $50-430$ & 160 & 1 & 60 \\
Gurnard & 158 & 220 & $150-300$ & $?$ & - & - \\
Silver trevally & 46 & 270 & $200-435$ & 280 & $?$ & - \\
Arrow squid & 170 & 160,300 & $90-360$ & 150 & 0.5 & 87 \\
Barracouta & 10 & 600 & $220-800$ & $450-600$ & $2-4$ & 50 \\
\hline
\end{tabular}

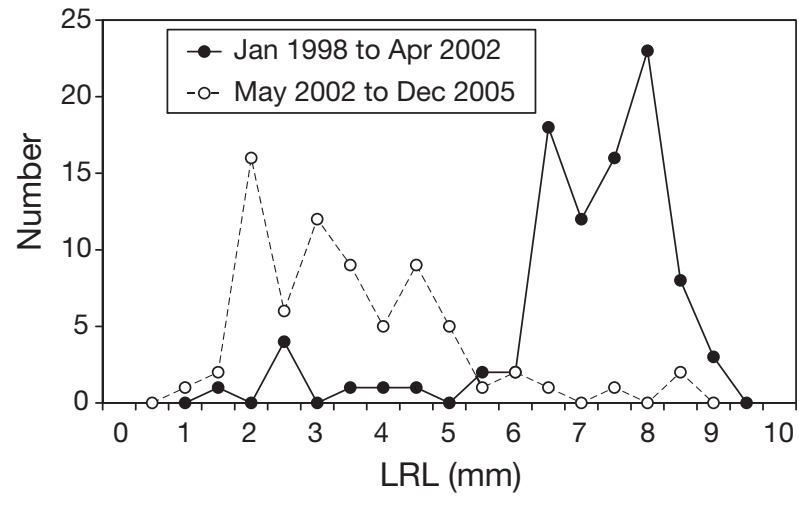

Fig. 2. Nototodarus gouldi. Frequency of lower-rostral lengths (LRL) of near-pristine beaks from arrow squid recovered from Australian fur seal scats. Data are separated temporally to emphasise a size change that occurred after April 2002

\section{Diet by MSST, CPUE and SOI}

The most parsimonious model when testing for the effect of MSST, CPUE and SOI on PC1 (redbait, leatherjacket, barracouta and bearded/red cod) was the MSST model (Table 8). There was very strong support for this model $\left(\mathrm{ER}=1.27 \times 10^{7}, \%\right.$ deviance $\left.=44.3\right)$, indicating that as MSST increased, less redbait were in the diet (Fig. 4a). The next best model was MSST+SOI, but it had a weighted Akaike's information criterion ( ${ }_{w} \mathrm{AIC}$ ) of 0.36 compared to 0.42 for the MSST model, and explained only a further $2.3 \%$ of the deviance. Given that redbait was such a dominant aspect of this component we also modelled it separately. Again the best model was MSST alone, with ER lending very strong support $\left(E R=1.89 \times 10^{6}, \%\right.$ deviance $\left.=46.2\right)$ for this model, indicating that as MSST declines, the amount of redbait in the diet increases (Fig. 4b).

\section{Monthly temperatures in redbait years versus other years}

Mean monthly SSTs were compared between years when redbait represented $>30 \%$ of prey (based on PFO), termed 'redbait' years (1998 to 2001), and $<10 \%$ of the prey, or 'other' years (2002 to 2005). The greatest monthly differences occurred in January to March, when water temperatures during 'other' years averaged 17.7 to $18.0^{\circ} \mathrm{C}$, as opposed to an average of 16.6 to $17.3^{\circ} \mathrm{C}$ in 'redbait' years; the mean difference between 'redbait' and 'other' years was $1.1^{\circ} \mathrm{C}$. Monthly temperatures over the rest of the year were on average $0.3^{\circ} \mathrm{C}$ (range -0.1 to $0.5^{\circ} \mathrm{C}$ ) warmer during 'other' years than during 'redbait' years.

Table 5. Arctocephalus pusillus doriferus. Reconstructed diet based on mass and occurrence of principal prey identified in scat remains of seals at Seal Rocks (see Table 2). When there were insufficient near-pristine otoliths to measure $\left({ }^{\mathrm{a}}\right)$, mean prey masses were taken from Littnan (2003), or were based on standard fish sizes in Furlani et al. (2007). In the absence of other data, we adopted a substitute value of $100 \mathrm{~g}$. Representative gurnard and leatherjackets were Lepidotrigla spp. and common bridled leatherjacket Acanthaluteres spilomelanurus, respectively. NA: numerical abundance, PFO: proportional frequency of occurrence. For taxonomic species names see Tables 2 \& 3

\begin{tabular}{|lccc|}
\hline Prey & Mass (g) & $\begin{array}{c}\text { Diet based } \\
\text { on NA (\%) }\end{array}$ & $\begin{array}{c}\text { Diet based } \\
\text { on PFO (\%) }\end{array}$ \\
\hline Barracouta & 826 & 30.4 & 48.3 \\
Redbait & 47 & 22.1 & 5.1 \\
Arrow squid & 458 & 8.5 & 8.2 \\
Jack mackerel & 77 & 7.8 & 4.7 \\
Gurnard & $150^{\mathrm{a}}$ & 7.1 & 6.5 \\
Bearded/Red cod & 96 & 6.8 & 5.1 \\
Tiger flathead & $1169^{\mathrm{a}}$ & 6.6 & 8.4 \\
Silver trevally & 270 & 2.1 & 2.2 \\
Calamari squid & 691 & 1.8 & 1.9 \\
Leatherjacket & 28 & 1.6 & 2.6 \\
Pink ling & $356^{\mathrm{a}}$ & 1.6 & 2.2 \\
Unknown sp.1 & $100^{\mathrm{a}}$ & 1.2 & 1.3 \\
Western red mullet & $148^{\mathrm{a}}$ & 0.9 & 1.3 \\
Silver dory & $100^{\mathrm{a}}$ & 0.4 & 0.7 \\
Maori octopus & 362 & 0.2 & 0.4 \\
Pale/keeled octopus & 101 & 0.2 & 0.2 \\
Sand flathead & $30^{\mathrm{a}}$ & 0.2 & 0.2 \\
Silverside & $30^{\mathrm{a}}$ & 0.2 & 0.2 \\
Silverbelly & 18 & 0.1 & 0.2 \\
Anchovy & 6 & 0.1 & 0.0 \\
\hline
\end{tabular}


Table 6. Arctocephalus pusillus doriferus. Principal components analysis on 12 species of seal prey from 51 samples showing the loadings (eigenvectors) for each species on the first 3 principal components (PCs). Blank cells indicate small but not zero values; any values between -0.1 and 0.1 have been excluded for ease of interpretation. Values for Unknown sp.1, silverbelly, western red mullet, silver trevally, silverside and arrow squid were all between -0.1 and 0.1 , so these species have been excluded from the table

\begin{tabular}{|llll|}
\hline & PC1 & PC2 & PC3 \\
\hline $\begin{array}{l}\text { Cumulative variance (\%) } \\
\text { Species loadings }\end{array}$ & 46.4 & 65.2 & 77.8 \\
Redbait & 0.935 & & \\
Leatherjacket & -0.167 & & 0.164 \\
Jack mackerel & & 0.935 & 0.136 \\
Barracouta & -0.210 & & \\
Bearded/Red cod & -0.216 & -0.255 & \\
Gurnard & & -0.170 & 0.400 \\
\hline
\end{tabular}

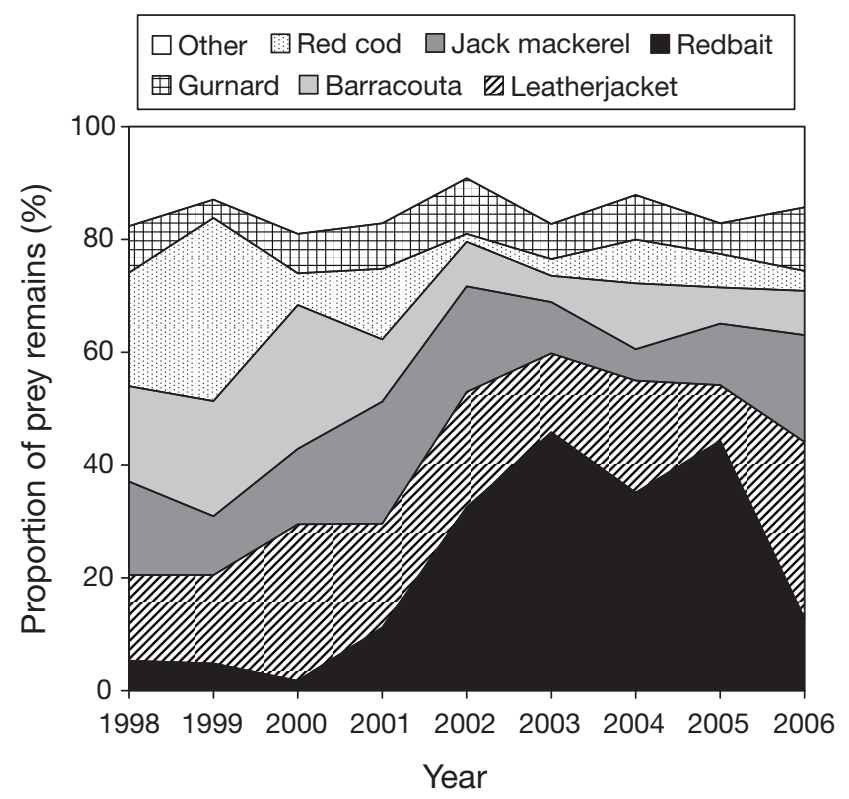

Fig. 3. Arctocephalus pusillus doriferus. Summary of the diet of seals at Seal Rocks, based on the proportional frequency of occurrence of prey remains in scats collected at a nearly bimonthly frequency. See Table 1 for species list

\section{DISCUSSION}

\section{Prey of Australian fur seals}

The diet of Australian fur seals at Seal Rocks was similar to those reported at other locations in recent years (Gales et al. 1993, Gales \& Pemberton 1994, Hume et al. 2004, Page et al. 2005, Littnan et al. 2007). Across their range, Australian fur seals prey on 60 to 70 species of fishes and cephalopods. The importance of particular prey varies geographically, but the principal species consumed remain the same, and include redbait, jack mackerel, barracouta, arrow squid, leatherjackets (Monocanthidae), gurnards (Triglidae), red cod and flathead species. Some inter-annual changes in diet have been reported previously, based on sampling over 2 or 3 yr at several sites (Hume et al. 2004, Littnan et al. 2007); the present study of over $9 \mathrm{yr}$ of routine sampling, however, is by far the longest time series of data available for this species, and one of the longest for any pinniped species.

Our sampling spanned an initial 4 yr of redbait scarcity in the seals' diet $(<10 \%$ of prey in 1998 to 2001), then $4 \mathrm{yr}$ of redbait prevalence in the diet $(>30 \%$ in 2002 to 2005) and a final year of redbait scarcity (in 2006). In years of redbait scarcity, they were replaced in the seal diet by increases in barracouta, leatherjackets and/or bearded cod. Other prey, such as jack mackerel and arrow squid, were prevalent throughout the study. The extended time scale of the variation, i.e. $4 \mathrm{yr}$ on one diet, then 4 yr on another, suggests an enduring multi-year influence on the seals' foraging environment (which contemporary satellite tracking studies indicate is western Bass Strait; Kirkwood et al. 2006, Arnould \& Kirkwood 2008). Oceanographic fluctuations may trigger such a cycling in this environment.

\section{Oceanographic influences}

In years with cooler SSTs in western Bass Strait, redbait were more prevalent in the diet of Australian fur seals visiting Seal Rocks ( $>30 \%$ of PFO). Differences in SSTs between 'redbait' and 'other' years were greatest in January to March, suggesting oceanic conditions at this time of year might influence the relative availabilities of prey.

Cooler waters in western Bass Strait generally result from a greater inflow of SASW and/or upwelling of Antarctic Surface Waters (Evans \& Middleton 1998, Middleton et al. 2007, Middleton \& Bye 2007). Conversely, warmer waters may result from weak current flow through the strait (leading to a long seawater residence time) and/or from increased warmer current inflows, notably from the SAC.

Little is known of oceanographic variations and their influences on productivity across southern Australia, including Bass Strait (Middleton et al. 2007). There are 2 known SOI-related variations, which, despite their absence in our models, might influence sea temperature in Bass Strait. Firstly, the onset of El Niño conditions tends to reduce winter-time circulation along Australia's southern shelf region without there being a compensatory increase in summer currents during El Niño summers (Middleton et al. 2007, Middleton \& Bye 2007). The reduced circulation appears to enhance 
Table 7. Arctocephalus pusillus doriferus. Results of 3 Generalised Linear Models examining effects of month and/or year on diet of seals expressed as the first 3 PCs of a PCA. The models related the PC scores for each sample to the month and year in which that sample was collected. The models are ranked in order of weighted Akaike information criterion, corrected for small samples ( ${ }_{w} A I C C_{c}$ ). $\log (\mathrm{L})$ : maximized log-likelihood of the model $\mathrm{AIC}_{\mathrm{c}}$ : selection criteria; $\Delta \mathrm{AIC}_{\mathrm{c}}$ : difference between the model's $\mathrm{AIC}_{c}$ value and the minimum $\mathrm{AIC}_{c}$ value; $\% \mathrm{DE}$ : percent deviance explained by model

\begin{tabular}{|lrrrrr|}
\hline & $\log (\mathrm{L})$ & $\mathrm{AIC}_{\mathrm{c}}$ & \multicolumn{1}{c}{$\Delta \mathrm{AIC}_{\mathrm{c}}$} & ${ }_{\mathrm{w}} \mathrm{AIC}_{\mathrm{c}}$ & $\% \mathrm{DE}$ \\
\hline PC1 & & & & & \\
Year & -169.766 & 346.043 & 0.000 & 0.741 & 30.996 \\
Month+year & -169.639 & 348.148 & 2.104 & 0.259 & 31.339 \\
Month & -179.201 & 364.912 & 18.869 & 0.000 & 0.102 \\
Null+null2 & -178.446 & 365.761 & 19.717 & 0.000 & 3.017 \\
PC2 & & & & & \\
Month+year & -147.119 & 303.107 & 0.000 & 0.659 & 29.196 \\
Month & -148.962 & 304.434 & 1.327 & 0.339 & 23.889 \\
Year & -154.230 & 314.971 & 11.864 & 0.002 & 6.422 \\
Null+null2 & -155.532 & 319.933 & 16.826 & 0.000 & 1.522 \\
PC3 & & & & & \\
Year & -141.895 & 290.300 & 0.000 & 0.681 & 20.052 \\
Month+year & -141.488 & 291.846 & 1.546 & 0.314 & 21.317 \\
Month & -147.142 & 300.794 & 10.494 & 0.004 & 1.787 \\
Null+null2 & -147.027 & 302.924 & 12.624 & 0.001 & 2.227 \\
\hline
\end{tabular}

Table 8. Arctocephalus pusillus doriferus. Results of the Generalised Linear Models examining the effect of the Southern Oscillation Index (SOI), fisheries catch per unit effort (CPUE) within $200 \mathrm{~km}$ of Seal Rocks and the annual mean sea surface temperature (MSST) in western Bass Strait on diet of seals, expressed as the first 3 PCs. The models are ranked in order of Akaike weights $\left({ }_{\mathrm{w}} \mathrm{AIC}_{\mathrm{c}}\right) . \log (\mathrm{L})$ : maximized log-likelihood of the model $\mathrm{AIC}_{\mathrm{c}}$ : selection criteria; $\Delta \mathrm{AIC}_{c}$ : difference between the model's $\mathrm{AIC}_{\mathrm{c}}$ value and the minimum $\mathrm{AIC}_{\mathrm{c}}$ value; $\% \mathrm{DE}$ : percent deviance explained by model

\begin{tabular}{|lrrrrr|}
\hline & $\log (\mathrm{L})$ & $\mathrm{AIC}_{\mathrm{c}}$ & ${ } \mathrm{AIC}_{\mathrm{c}}$ & ${ }_{\mathrm{w}} \mathrm{AIC}_{\mathrm{c}}$ & ${ }^{\circ} \mathrm{DE}$ \\
\hline MSST & -160.386 & 327.295 & 0.000 & 0.402 & 46.222 \\
SOI+MSST & -159.301 & 327.491 & 0.196 & 0.364 & 48.507 \\
MSST+CPUE & -160.377 & 329.643 & 2.349 & 0.124 & 46.242 \\
MSST+CPUE+SOI & -159.301 & 329.965 & 2.670 & 0.106 & 48.507 \\
SOI+CPUE & -164.518 & 337.926 & 10.631 & 0.002 & 36.557 \\
SOI & -166.043 & 338.607 & 11.313 & 0.001 & 32.568 \\
CPUE & -170.307 & 347.136 & 19.841 & 0.000 & 20.027 \\
Null3 & -175.585 & 357.691 & 30.397 & 0.000 & 1.229 \\
Null5 & -175.846 & 358.213 & 30.919 & 0.000 & 0.193 \\
Null4 & -175.881 & 358.283 & 30.989 & 0.000 & 0.053 \\
Null3+null4 & -175.562 & 360.013 & 32.719 & 0.000 & 1.318 \\
Null3+null5 & -175.584 & 360.056 & 32.762 & 0.000 & 1.233 \\
Null4+null5 & -175.833 & 360.554 & 33.259 & 0.000 & 0.245 \\
Null3+null4+null5 & -175.561 & 362.486 & 35.192 & 0.000 & 1.322 \\
\hline
\end{tabular}

one does not exist, or the temporal scales we used were not sufficiently predictive. There may be a delay between cause and effect, or a confounding influence, for example redbait drawn into Bass Strait by a single event may remain there for several years.

Other meteorological conditions can influence annual differences in Bass Strait water temperatures. In some years, single storm events may draw lenses of cold water into western Bass Strait (Blackman et al. 1987). On a longer time scale, the ACW pulses colder than average, then warmer than average Antarctic waters in a northerly direction in a 4 to 5 yr cycle (White \& Peterson 1996). Also, the ACW influences a near-decadal cycle in zonal (westerly) and meridional (southerly) winds, and this cycle has been linked to variability in fish recruitment patterns (Thresher 1994) and cetacean stranding periodicity in southeastern Australia (Evans et al. 2005). Further oceanographic investigations in the Bass Strait region are required to help clarify the way in which currents and meteorological conditions may influence sea temperatures.

\section{Inter-annual patterns in the prey}

Redbait and jack mackerel are species that commonly school together in south-eastern Australian waters (Williams \& Pullen 1993), and annual variability in their surface schooling on the east coast of Tasmania has been related to sea temperature and ENSO cycles (Young et al. 1993). Sea temperatures along the east coast of Tasmania are influenced by changes in the extent of the East Australia Current and the position of its convergence with SASW (Harris et al. 1991). In La Niña years,

upwelling along the southern Australian coast (Middleton et al. 2007), providing cold water that may enter Bass Strait. Secondly, the warm EAC is enhanced in La Niña years and extends past Bass Strait to the east Tasmanian coast (Harris et al. 1991), and this current may partially block westward flow through the strait, thus causing it to warm. That we found no direct link between seal diet and the SOI may indicate that the East Australia Current is stronger than average and extends further down the Tasmanian east coast, preventing SASW from dominating shelf waters. Having this warmer, nutrient poor water on the shelf reduces primary productivity (Harris et al. 1991), which in turn reduces the abundance of a key zooplankton species, the krill Nyctiphanes australis, which is an important prey of redbait and jack mack- 


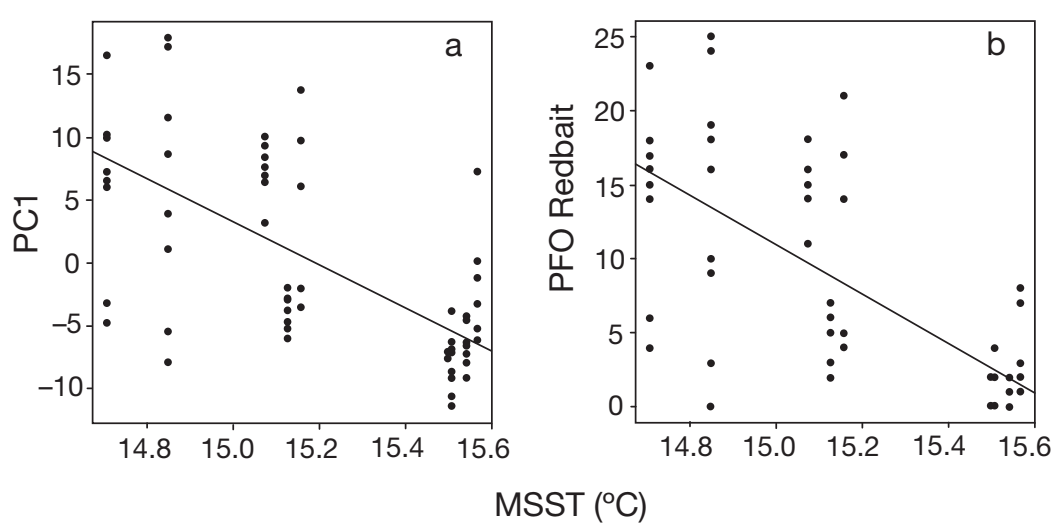

Fig. 4. Arctocephalus pusillus doriferus. Graphical representation of the main models identified by the GLM. (a) PC1 in relation to mean sea surface temperature (MSST): $\mathrm{PC} 1=260.44-\mathrm{MSST} \times 17.15$. (b) Proportional frequency of occurrence $(\mathrm{PFO})$ of redbait in seal diet in relation to MSST: PFO Redbait = $260.488-$ MSST $\times 16.635$

erel (Young et al. 1993). Surface schooling behaviours of these fish appear linked to krill availability (Young et al. 1993). A purse-seine fishery that targeted surface schools of jack mackerel and redbait during the 1980s and 1990s caught up to $40000 \mathrm{t}$ in some years and $<5000 \mathrm{t}$ in others, with the variation being largely dependant on whether or not the fish surface schooled (Williams \& Pullen 1993, Welsford \& Lyle 2003).

The known behavioural response of redbait and jack mackerel to water temperature on the east coast of Tasmania may explain variations in the prevalence of these species in western Bass Strait. If cooler surface waters over the shelf to the west of Bass Strait were to bring redbait and jack mackerel up from deeper outer shelf waters toward the surface, currents would be more likely to flush them into the Bass Strait basin, making them available to the fur seals foraging from Seal Rocks. This scenario, however, suggests that redbait and jack mackerel behave similarly, so that their availabilities to the seals should correlate; however, only redbait prevalence fluctuated dramatically in the seals' diet. The reason for this could be that the seals ate mainly juveniles of these species, and the distributions of the juveniles may differ.

Although schooling together when co-occurring, redbait may be a more oceanic species than jack mackerel. Redbait has a broader distribution than jack mackerel, living over isolated sea mounts and in association with continental shelves of all Southern Hemisphere continents (except Antarctica), while jack mackerel inhabits just southern Australian and New Zealand shelf waters (Kailola et al. 1993, Welsford \& Lyle 2003). Jack mackerel juveniles occur across the shelf and in sheltered coastlines and bays (Kailola et al. 1993, Williams \& Pullen 1993, Welsford \& Lyle 2003). Redbait juveniles, in con- trast, appear to be most abundant offshore and can occur at depths of up to $500 \mathrm{~m}$ (Roschin 1985). Moreover, although purse-seine and mid-water trawl fisheries off the Tasmanian east coast have taken largely adult jack mackerel (Jordan et al. 1995), the redbait catch was dominated by juveniles (Welsford \& Lyle 2003). Thus, within Bass Strait, the coastal jack mackerel juveniles may be more consistently available to seals foraging from Seal Rocks than the outer-shelf redbait juveniles, which may require inflows of cooler waters from the outer shelf to bring them into the seals' range. More data are needed on the biology of these fishes (particularly in shelf waters west of Bass Strait) to better explain variations in their availabilities to the seals.

Patterns in the sizes of arrow squid eaten by Australian fur seals may also be related to sea temperatures in different years. Smaller squid were caught by Australian fur seals in years of cooler SST in western Bass Strait (i.e. 2002 to 2005, Fig. 2). Cohorts of arrow squid may hatch in all months of the year (Jackson et al. 2005), unlike most fish species which spawn during a single period of the year (e.g. spring-time), and each squid cohort lives for 1 yr. Generally, squid grow faster and to a larger size in warm waters than in cool waters (Jackson et al. 2003). This pattern accords with the Australian fur seals predation on larger arrow squid between 1998 and early 2002, when Bass Strait surface waters were warmer than average, and smaller squid between late 2002 and 2005, when the waters were cooler.

\section{Long-term trends}

While 9 yr may represent a long sampling period relative to previous diet studies, it spans the diets of only several generations of Australian fur seals, which mature at 3 to 6 yr (longevity is about $20 \mathrm{yr}$ ) (Warneke \& Shaughnessy 1985); 9 yr does not encompass long duration climatic cycles. The diet needs to placed into perspective by recognising longer term influences on the seal foraging environment. For example, the benthic foraging Australian fur seal probably originates from an Indian Ocean migration made by the pelagic foraging Cape fur seal Arctocephalus pusillus pusillus of southern Africa (Wynen et al. 2001). The benthic foraging behaviour of Bass Strait seals is likely to be an adaptation to prey assemblages available in southeastern Australian waters. 
Over the past $200 \mathrm{yr}$, anthropogenic changes to coastal environments have modified the prey available to Australian fur seals. Firstly, the seals were harvested to near extinction between 1798 and the 1820s (Warneke \& Shaughnessy 1985). Since the 1970s, though, Australian fur seal numbers have almost doubled in what appears to be a recovery from the earlier exploitation (Kirkwood et al. 2005). Secondly, commercial fisheries commenced in the late 1800s, initially targeting coastal, then shelf and, in the 1970s, off-shelf species (Kailola et al. 1993, Tilzey \& Rowling 2001). Catch statistics have recorded subsequent declines of $>50 \%$ in most major fisheries (Edgar et al. 2005). Thirdly, in 1995 and 1998, a herpes virus originating from fishfarms in South Australia caused the largest monospecific fish kill ever recorded, that of the local pilchard Sardinops sagax neopilchardus (Ward et al. 2001). Pilchards had been the primary prey of many marine species, including seabirds (Bunce \& Norman 2000, Chiaradia et al. 2003). The removal of the seals and their recent recoveries, fisheries impacts and the catastrophic loss of pilchards have undoubtedly altered marine trophic structures along the southern Australian continental shelf.

Into the future, anthropogenic effects and oceanographic trends are likely to continue to influence ecosystem structure, prey availability and population trends of Australian fur seals. Climate change is resulting in an overall increase in mean SST (Poloczanska et al. 2007). On the east coast of Tasmania, for example, an increase of $>1{ }^{\circ} \mathrm{C}$ has been recorded since the 1940s (Crawford et al. 2000). Future increases are likely to reduce surface water productivity and have additive effects through the food chain to the seals.

Through routine monitoring of seal diet, we recorded ecosystem fluctuations that have not been previously recognised in Bass Strait. At South Georgia, in the south Atlantic Ocean, inter-annual variability in the fish diet of Antarctic fur seals Arctocephalus gazelle has also been related to changes in sea-surface temperature and its influence on the availability of an important prey, Antarctic krill Euphausia superba (Reid et al. 2006). Elsewhere, inter-annual variability in otariid diet has been linked to catastrophic changes in whole prey assemblages caused by strong El Niño events (Trillmich \& Ono 1991), or the causes of fluctuations have been unclear, either due to complicated ecosystem links or short durations of study. Clearly, long-term data sets are the key to describing interannual variability in otariid diet, and their causes and consequences.

Acknowledgements. We thank the many sample collection assistants, J. Kemp (PhD student at Melbourne University) for supplying data on Pseudophycis species in the seal diet and M. van Polanen Petel, F. Iqbal, A. Jordan and 3 anonymous referees for constructive comments on earlier drafts. This research was conducted under ethics permits from the Phillip Island Nature Park AEEC and Wildlife Permits from the Victorian Department of Sustainability and the Environment.

\section{LITERATURE CITED}

Arnould JPY, Kirkwood R (2008) Habitat selection in a benthic diver: the foraging areas of female Australian fur seals (Arctocephalus pusillus doriferus). Aquat Conserv: Mar Freshw Ecosyst 17:S53-S67

Blackman DR, Hinwood JB, Lleonart GT (1987) Temperature anomaly in western Bass Strait. Mar Freshw Res 38: 191-195

Bunce A, Norman FI (2000) Changes in the diet of the Australasian gannet (Morus serrator) in response to the 1998 mortality of pilchards (Sardinops sagax). Mar Freshw Res 51:349-353

Burnham KP, Anderson DR (2002) Model selection and multimodal inference: a practical information-theoretic approach. Springer-Verlag, New York

Chiaradia A, Costalunga A, Kerry K (2003) The diet of little penguins at Phillip Island, Victoria, in the absence of a major prey - pilchards. Emu 103:43-48

Crawford CM, Edgar GJ, Cresswell G (2000) The Tasmanian region. In: Shephard C, Zann LP (eds) Seas at the millennium. Pergamon, Amsterdam, p 647-660

Edgar GJ, Samson CR, Barrett NS (2005) Species extinction in the marine environment: Tasmania as a regional example of overlooked losses in biodiversity. Conserv Biol 19: $1294-1300$

Evans SR, Middleton JF (1998) A regional model of shelf circulation near Bass Strait: a new upwelling mechanism. J Phys Oceanogr 28:1439-1457

Evans K, Thresher R, Warneke RM, Bradshaw CJA, Pook M, Thiele D, Hindell MA (2005) Periodic variability in cetacean strandings: links to large-scale climate events. Biol Lett 1:147-150

Fea NI, Harcourt R, Lalas C (1999) Seasonal variation in the diet of New Zealand fur seals (Arctocephalus forsteri) at Otago Peninsula, New Zealand. Wildl Res 26:147-160

Furlani D, Gales R, Pemberton D (2007) Otoliths of common temperate Australian fish: a photographic guide. CSIRO Publishing, Melbourne

> Gales R, Pemberton D (1990) Seasonal and local variation in the diet of the little penguin, Eudyptula minor, in Tasmania. Aust Wildl Res 17:231-259

Gales R, Pemberton D (1994) Diet of the Australian fur seal in Tasmania. Aust J Mar Freshwater Res 45:653-664

Gales R, Pemberton D, Lu CC, Clarke MR (1993) Cephalopod diet of the Australian fur seal: variation due to location, season and sample type. Aust J Mar Freshwater Res 44: $657-671$

Gibbs CF, Tomczak M, Longmore AR (1986) The nutrient regime of Bass Strait. Aust J Mar Freshwater Res 37: 451-466

> Harcourt RG, Bradshaw CJA, Dickson K, Davis LS (2002) Foraging ecology of a generalist predator, the female New Zealand fur seal. Mar Ecol Prog Ser 227:11-24

Harris GP, Griffiths FB, Clementson LA, Lyne V, van der Doe $H$ (1991) Seasonal and interannual variability in physical processes, nutrient cycling and the structure of the food chain in Tasmanian shelf waters. J Plankton Res 13: 109-131 
Hawkins SJ, Southward AJ, Genner MJ (2003) Detection of environmental change in a marine ecosystem - evidence from the western English Channel. Sci Total Environ 310:245-256

Hindell MA, Bradshaw CJA, Harcourt R, Guinet C (2003) Ecosystem monitoring: Are seals a potential tool for monitoring change in marine systems? In: Gales NJ, Hindell MA, Kirkwood R (eds) Marine mammals fisheries, tourism and management issues. CSIRO Publishing, Melbourne, p 330-343

- Horn PL (2002) Age estimation of barracouta (Thyrsites atun) off southern New Zealand. Mar Freshw Res 53:1169-1178

> Hume F, Hindell MA, Pemberton D, Gales R (2004) Spatial and temporal variation in the diet of a high trophic level predator, the Australian fur seal (Arctocephalus pusillus doriferus). Mar Biol 144:407-415

Jackson GD, McGrath-Steer B, Wotherspoon S, Hobday AJ (2003) Variation in age, growth and maturity in the Australian arrow squid Nototodarus gouldi over time and space - what is the pattern? Mar Ecol Prog Ser 264: $57-71$

> Jackson GD, Wotherspoon S, McGrath-Steer B (2005) Temporal population dynamics in arrow squid Nototodarus gouldi in southern Australian waters. Mar Biol 146: 975-983

Jordan AR, Pullen G, Marshall J, Williams H (1995) Temporal and spatial patterns of spawning in jack mackerel, Trachurus declivis (Pisces: Carangidae), during 1988-91 in eastern Tasmanian waters. Mar Freshw Res 46:831-842

Kailola PJ, Williams MJ, Stewart PC, Reichelt RE, McNee A, Grieve C (1993) Australian fisheries resources. Bureau of Rural Science and Fisheries Resource Development Corporation Publication, Canberra

Kidson JW, Renwick JA (2002) The southern hemisphere evolution of ENSO during 1981-99. J Clim 15:847-863

Kirkwood R, Gales R, Terauds A, Arnould JPY and others (2005) Pup production and population trends of the Australian fur seal Arctocephalus pusillus doriferus. Mar Mamm Sci 21:260-282

Kirkwood R, Lynch M, Gales N, Dann P, Sumner M (2006) Foraging strategies of an adult, male otariid: the Australian fur seal (Arctocephalus pusillus doriferus). Can J Zool 84:1781-1788

Lea MA, Cherel Y, Guinet C, Nichols PD (2002) Antarctic fur seals foraging in the Polar Frontal Zone: inter-annual shifts in diet as shown from fecal and fatty acid analyses. Mar Ecol Prog Ser 245:281-297

Lewis F (1930) Seals on the Victorian coast and their feeding habits. Austral Mus Mag 4:39-44

Littnan CL (2003) Approaches to studying the foraging ecology of the Australian fur seal Arctocephalus pusillus doriferus in northern Bass Strait. PhD thesis, Macquarie University, Sydney

Littnan CL, Arnould JPY, Harcourt RG (2007) Effect of proximity to the shelf edge on the diet of female Australian fur seals. Mar Ecol Prog Ser 338:257-267

Lu CC, Ickeringill R (2002) Cephalopod beak identification and biomass estimation techniques: tools for dietary studies of southern Australian finfishes. Mus Victoria Sci Rep 6:1-65

Marshall J, Pullen G, Jordan AR (1993) Reproductive biology and sexual maturity of female jack mackerel, Trachurus declivis (Jenyns), in eastern Tasmanian waters. Aust J Mar Freshwater Res 44:799-809

McNally J, Lynch DD (1954) Notes on the food of Victorian seals. Office of the Director of Fisheries and Game, Melbourne
Middleton JF, Bye JAT (2007) A review of shelf-slope circulation along Australia's southern shelves: Cape Leeuwin to Portland. Prog Oceanogr 75:1-41

> Middleton JF, Arthur C, van Ruth P, Ward TM and others (2007) El Niño effects and upwelling off South Australia. J Phys Oceanogr 37:2458-2477

Newell BS (1961) Hydrology of south-eastern Australian waters: Bass Strait and New South Wales tuna fishing area. Technical Paper 10, CSIRO Australia Division of Fisheries and Oceanography, Hobart

Page B, McKenzie J, Goldsworthy SD (2005) Dietary resource partitioning among sympatric New Zealand and Australian fur seals. Mar Ecol Prog Ser 293:283-302

> Pearce AF, Phillips BF (1988) ENSO events, the Leeuwin Current, and larval recruitment of the western rock lobster. ICES J Mar Sci 45:13-21

Poloczanska ES, Babcock RC, Butler A, Hobday AJ and others (2007) Climate change and Australian marine life. Oceanogr Mar Biol Annu Rev 45:407-478

> Reid K, Davis D, Staniland IJ (2006) Spatial and temporal variability in the fish diet of Antarctic fur seal (Arctocephalus gazella) in the Atlantic sector of the Southern Ocean. Can J Zool 84:1025-1037

Roschin EA (1985) Some biological properties of redbait, Emmelichthys nitidus (Emmelichthydae), from a seamount in the notal zone of the Indian Ocean. J Ichthyol 25: $44-50$

Sandery PA, Kämpf J (2005) Winter-spring flushing of Bass Strait, south-eastern Australia: a numerical modelling study. Estuar Coast Shelf Sci 63:23-31

Staniland IJ (2002) Investigating the biases in the use of hard prey remains to identify diet composition using Antarctic fur seals (Arctocephalus gazella) in captive feeding trials. Mar Mamm Sci 18:223-243

Thresher RE (1994) Climatic cycles may explain fish recruitment in south east Australia. Aust Fish 53:20-22

- Tilzey RDJ, Rowling KR (2001) History of Australia's south east fishery: a scientist's perspective. Mar Freshw Res 52:361-375

Tollit DJ, Steward MJ, Thompson PM, Pierce GJ, Santos MB, Hughes S (1997) Species and size differences in the digestion of otoliths and beaks: implications for estimates of pinniped diet composition. Can J Fish Aquat Sci 54: 105-119

Trillmich F, Ono KA (1991) Pinnipeds and El Niño: responses to environmental stress. Springer-Verlag, New York

> Ward TM, Hoedt F, McLeay L, Dimmlich WF and others (2001) Effects of the 1995 and 1998 mass mortality events on the spawning biomass of sardine, Sardinops sagax, in South Australian waters. ICES J Mar Sci 58:865-875

Warneke RM, Shaughnessy PD (1985) Arctocephalus pusillus, the South African and Australian fur seal: taxonomy, evolution, biogeography, and life history. In: Ling JK, Bryden MM (eds) Studies of sea mammals in south latitudes. South Australian Museum, Adelaide, p 53-77

Welsford DC, Lyle JM (2003) Redbait (Emmelichthys nitidus): a synopsis of fishery and biological data. Report No. 20, Tasmanian Aquaculture and Fisheries Institute, University of Tasmania, Hobart

White WB, Peterson RG (1996) An Antarctic circumpolar wave in surface pressure, wind, temperature and sea-ice extent. Nature 380:699-702

Williams H, Pullen G (1993) Schooling behaviour of jack mackerel Trachurus declivis (Jenyns) observed in the Tasmanian purse seine fishery. Aust J Mar Freshw Res 44: $577-587$

Wilson SG, Taylor JG, Pearce AF (2001) The seasonal aggre- 
gation of whale sharks at Ningaloo Reef, Western Australia: currents, migrations and the El Niño/Southern Oscillation. Environ Biol Fishes 61:1-11

Wynen LP, Goldsworthy SD, Insley SJ, Adams M and others (2001) Phylogenetic relationships within the eared seals (Otariidae: Carnivora): implications for the historical bio-

Editorial responsibility: Yves Cherel, Viller-en-Bois, France geography of the family. Mol Phylogenet Evol 21: 270-284 Young JW, Jordan AR, Bobbi C, Johannes RE, Haskard K, Pullen G (1993) Seasonal and interannual variability in krill (Nyctiphanes australis) stocks and their relationship to the fishery for jack mackerel (Trachurus declivis) off eastern Tasmania, Australia. Mar Biol 116:9-18

Submitted: April 14, 2008; Accepted: June 27, 2008

Proofs received from author(s): September 24, 2008 